\title{
圈 \\ Risk-Return Trade-off in Emerging Markets: Evidence from Dhaka Stock Exchange Bangladesh.
}

\author{
Abu T. Mollik ${ }^{2}$ and M. Khokan Bepari ${ }^{3}$
}

\begin{abstract}
This paper attempts to measure the risk and return relationship in Dhaka Stock Exchange (DSE). The study reports a statistically significant positive relationship between risk and return both at the individual security level and at the portfolio level, confirming the theoretical predictions and empirical findings on this issue in developed markets. Although portfolio risk and returns are found to be significantly positively related in general, some inconsistencies were revealed in the context of relative risk for high risk portfolios, suggesting the existence of some anomalies or mispricing in high risk assets. These findings have important implications for investment decisions at the DSE in that the investors may be able to create profitable investment strategies using the mispricing information.
\end{abstract}

Keywords: Risk-Return trade-off, Mean-variance CAPM Model, Systematic risk, Portfolio beta, Emerging market, Dhaka Stock Exchange

JEL Code(s): C12, C23, D53, G11, G12, N 15

\footnotetext{
${ }^{1}$ Acknowledgements: We express our sincere gratitude to the two anonymous reviewers for their valuable detailed comments and suggestions which have helped improve our paper.

${ }^{2}$ University of Canberra. abu.mollik@canberra.edu.au

${ }^{3}$ University of Canberra, Khokan.Bepari@canberra.edu.au
} 
AABFJ | Volume 9, no. 1, 2015

\section{Introduction}

Risk-return trade-off is an important topic in finance. It plays a crucial role in most financial decision-making processes of a firm - its asset valuation, investment, financing and distribution decisions. The expected return of an asset rises with risk/ uncertainty because investors hold a risky asset (security) if they are compensated with commensurably higher returns. In the capital asset pricing model (CAPM) framework, systematic risk or beta is the only relevant risk of an asset and it can be measured by the covariance of the asset return with the market return or by the covariance with other common factors related to investors' marginal utility in Merton's (1973) intertemporal capital asset pricing model (ICAPM). If market portfolio (index) is the asset, the risk can be measured by the conditional variance of market return. Beta is the only asset/security specific parameter that influences the equilibrium return on a risky stock (Mandelker \& Rhee, 1984).

Empirical evidence for this contention, however, is inconclusive. Fama and MacBeth (1973) find support for the risk-return relationship in a cross-section of companies. However, empirical evidence in the 1990s (e.g. Fama \& French, 1992, 1996; Jegadeesh, 1992) indicates that betas are not statistically related to returns. Indeed, Fama and French (1992) reveal a negative relationship between risk and return in terms of single factor CAPM and suggest that a multi-index model as the more realistic approach for measuring the risk in the market. Their work stimulated a significant amount of research in the area, especially in estimating portfolio risk and returns. Bartholdy and Peare (2004) find that the ability of beta to explain differences in returns in subsequent periods ranges from a low of $0.01 \%$ to a high of $11.73 \%$ across years and is at best 3\%, on average. Further, the Fama and French three factor model does not do much better; although the size factor is found to be significant with the R-square at around only $5 \%$. The low explanatory power of the simple estimation technique- for both the CAPM and the Fama and French model - suggests that neither model is useful for estimating cost of equity, at least for the simple estimation techniques used in the study. The finance practitioners, however, seem to prefer CAPM for estimating cost of equity (see, for example, Bruner et al., 1998 \& Graham \& Harvey, 2001). In the context of market portfolios, Darrat et al. (2011), Bali et al. (2009), Bali and Peng (2006) and Ghysels et al. (2005) lend statistically significant support for a positive relationship, while Goyal and Santa-Clara (2003), Harvey (2001) and Glosten et al. (1993) fail to detect any positive relationship. In fact, Harvey (2001) and Glosten et al. (1993) reported a reverse relationship.

Most prior research focuses on mature markets such as those in the U.S. and Europe (see, for instance, Nawalkha \& Schwarz, 2004; Jagannathan \& McGrattan, 1995). Although the tests of CAPM are extremely sensitive to the use of market proxy since the market portfolio needs to be ex-ante mean variance efficient (Focardi \& Fabozzi, 2004), the model has been used in developed and emerging markets alike. The issue of relating risk and return in the emerging markets, however, differs from that of developed markets since emerging markets are characterized by: (i) high volatility, (ii) low integration and correlation with the world market, and consequently (iii) high diversifiable risk (Harvey 1995a, 1995b). Surprisingly, a few of the studies found evidence to support the validity of CAPM despite imperfect nature of those emerging markets, contradicting the theoretical prediction of the model in such markets (e.g., Guy, 1977; Hawawini \& Mitchel, 1982; Sauer \& Murphy, 1992; and Amanulla \& Kamaiah, 1998). A non-trivial number of studies, however, failed to establish a linear risk-return relationship in emerging markets. For example, for a group of 19 emerging markets, including Pakistan, using eight year data from 1986 to 1993, Claessens et al. (1995) conclude that while similar factors govern the cross-section of emerging market 
return, the signs of most of the coefficients are contrary to those found in developed markets. It is interesting to note that in their study, Pakistan was the only country with a significant negative beta risk premium. Estrada (2000) concludes that betas and stock returns in emerging markets do not seem to be related. Bark (1991) and Huang (1997) report a negative risk/return relationship for three Asian markets - Singapore, South Korea and Taiwan, respectively. Cheung et al. (1993) also report a weak risk/return relation for South Korea and Taiwan. Cheung and Wong (1992) find a weak relationship between risk and return in the Hong Kong market. Molla and Mobarek (2009) using the daily returns and Dimson corrected beta, suggested that the overall market movements did not influence the share returns in the Botswana Stock Exchange for the period of 2000-2005. Ward and Muller (2012) found that portfolios constructed on the basis of ranked beta exhibited a monotonic inverse relationship to what the CAPM prescribes, for most of the time series. They suggested that the use of the single beta CAPM is therefore inappropriate.

This paper focuses on Dhaka Stock Exchange (DSE) in Bangladesh. It is important to explore the risk-return relationship of companies listed on DSE for various reasons. First, Bangladesh is a rapidly emerging market in South Asia and currently is experiencing low liquidity and market capitalization ratio, thin trading, lack of institutional investors, limited number of mutual funds and investors indicating their preference for short-term outcomes (and exuberantly so). Bepari and Mollik (2008) find that Bangladesh stock market is still at an early stage of its growth path with a small market size relative to GDP and is characterized by poor liquidity and high market concentration. These apparently contradict with the assumptions of CAPM and market efficiency under which the CAPM operates. However, the widespread use of CAPM beta as the reference of company specific risk worldwide, including emerging markets makes it interesting to examine how the risk and return behave in emerging markets like DSE. Second, the DSE may be important for international diversification in that emerging markets have great potential for equity risk diversification and they also offer higher average returns than the developed markets (Harvey, 1995). The benefit from international diversification, however, is much reduced if the returns to emerging markets are driven by factors originating outside of the market, and this would be the case when the market under consideration is more closely integrated with the world markets (Wolf, 1998). To date, DSE was one of the stock markets least affected by the recent global financial crisis (GFC). In fact, while most of the world markets declined during the global financial crisis, stock prices in DSE continually rose, suggesting it was less integrated with the developed markets and therefore more potential for international diversification with higher average returns than the developed markets. The extent of diversification benefits and the risk premium, however, are subject to formal investigation, warranting empirical evidence specific to a particular emerging market. The findings of the study will be of great value to national and international portfolio investors in DSE.

Earlier researches on DSE (for example, Rahman \& Baten 2006, Alam et al. 2007, Ali et al. 2010, and Hasan et al. 2011) have reported mixed evidence regarding risk-return relationship, using various different models and data sets. Rahman and Baten (2006) tested the validity of CAPM applying the Fama-French (1992) Three-Factor model to a data set of 123 DSE listed non-financial companies. They found the beta and size (sales) to be statistically significantly related (beta was inversely related) to returns in their cross-sectional models. They used five-yearly average cross-section and pooled time-series and cross-section models log of daily frequency of returns, including lag and lead, to estimate the individual equity beta. Alam et al. (2007) showed an inverse risk and return relationship in the DSE plugging in the simple average of market returns over 1994 to 2005 periods and Bangladesh 
T-bill rate as risk-free rate of return in the famous single index market model equation. Their analysis is too simplified to establish the findings and the average return calculation could be biased downward by including the period of market crash in 1996, therefore, re-enforcing the inverse relationship. Ali et al. (2010) test the validity of CAPM in the Dhaka Stock Exchange (DSE) using Fama and Macbeth (1973) approach to 160 companies for the period from July 1998 to June 2008. They find a positive, but non-linear and statistically insignificant relation between 24-months rolling monthly risk (beta) and return. They commented that beta cannot be used as the main and only source of risk. Hasan et al. (2011) investigated the risk-return relationship in DSE under CAPM framework using monthly stock returns for 80 nonfinancial companies for the period of January 2005 to December 2009. They observed that the intercept term is significantly different from zero and a positive, but insignificant relationship between beta and share return. They further observed the existence of linearity of the security market line and the unique risk and the interaction were insignificant during their study period. Faruque (2012) investigated the performance of Arbitrage Pricing Theory (APT) and found one significant macroeconomic factor, exchange rate, as being priced in DSE out of seven macroeconomic variable tested. He used monthly data sets of 23 most actively traded stocks and macroeconomic variables covering the period from December 1995 to November 2010.

Considering the fact that betas of individual stocks in DSE are unstable and the instability increases with the holding periods (Mollik \& Bepari, 2010) and that two recent studies (Ali et al., 2010 \& Hassan et al., 2011) revealed a positive, but inconsistent relationship between beta and return using the data sets of different sample periods and frequencies, this study re-examines the issue in a more comprehensive manner for evidence of risk and return relationship in DSE. We used a separate and relatively stable sample period of 2000-2007. We reported results based on a different method of portfolio formation, in addition to the conventional beta-ranked portfolios and individual stocks. We applied the simple standard CAPM model.

The rest of the paper is organized as follows: the next section briefly discusses the development of asset pricing models and risk-return relationship and the objectives of the study. In sections 3 we discuss the data and methodology. In section 4 we present the results and discussion. Section 5 concludes the paper indicating limitations and further research prospects.

\subsection{Models of Asset Pricing and Risk-return relationship}

Researchers have used various models to explain the risk-return relationship of an asset in several different markets in the world. The famous Capital Asset Pricing Model (CAPM) (independently developed by Sharpe, 1964; Lintner, 1965a; Mossin, 1966 \& Black, 1972) is the fundamental model that first establishes a linear relationship between risk and return of an asset and states that beta or systematic risk is the only relevant risk measure of an asset in this context. The riskiness of a stock relative to the risk of the market portfolio is termed as its beta or systematic risk. The model suggests a positive trade-off between beta and expected returns. Based on some simplifying assumptions, the CAPM is expressed as a linear function of a risk-free rate, beta and the expected risk premium as follows:

$$
\left.R_{i}=R_{f}+\beta_{j}\left(R_{m}-R_{f}\right)\right)
$$

where, $R_{i}=$ expected return on asset $i ; R_{f}=$ risk-free or zero-beta rate of return; $\beta_{i}=$ beta of company $i ; R_{m}=$ the market return and $\left.\left(R_{m}-R_{f}\right)\right)=$ the market risk premium. 
However, the inability of the single market factor (index) CAPM to explain the crosssectional spread in average returns, as discussed earlier, has led to the development of alternative asset pricing models. Ross (1976) suggested the arbitrage pricing theory (APT), as an alternative, including other factors in the model to explain the cross-sectional return variations. The APT, however, provided no specific clue about the factors, their number and/ or the identification. Researchers, therefore, have used models including various empirical factors based on the pricing anomalies by the CAPM. Fama and French's (1993) three-factor and five-factor models are the most prominent ones among them. They suggested a threefactor model containing the market factor, SMB, and HML, and a five-factor model including additional two bond factor portfolios, term spread and default spread, with the three-factor model. Unsurprisingly, Fama and French's (1993) models were also not above criticism as many researchers found a number of other variables to be related to beta and returns. Among others, Kim (2006) suggested a two-factor model containing the market factor and the earnings information uncertainty risk factor. Chen et al. (2010) suggested a three-factor model containing the market factor, an investment factor, and a return on asset factor, suggesting that their model outperforms traditional asset pricing models in explaining anomalies associated with short-term price continuation, accruals, and stock valuation ratios. In Fama and French (2004) and Strugnell et al. (2011) some share characteristics such as size (market capitalization), price to earnings (value versus growth) and resources versus nonresources shares have been shown to be associated with share returns.

Considering the static single-period nature of the CAPM and that its failure in explaining the variations in cross-sectional average returns could be attributed to this static nature, some multi-period or continuous time dynamic models have also been suggested as alternatives by several researchers. Consumption-based CAPM (CCAPM) of Rubinstein (1976), Lucas (1978) and Breeden (1979) and the Intertemporal CAPM (ICAPM) of Merton (1973) models belong to this string of dynamic asset pricing models. The ICAPM requires including some state factors additional to the market index factor. Merton (1973) argues that when there is stochastic variation in investment opportunities, there will be risks associated with innovations in the state variables that describe the investment opportunities. Several ICAPM-motivated models (for example, Campbell, 1996; Vassalou, 2003; Kim et al., 2011) have been suggested according to the choice of such state variables. Campbell (1996) used the relative Treasury-bill rate, the dividend yield, the growth rate in real labor income, and the term spread as the state variables, while Vassalou (2003) and Kim et al. (2011) suggested future GDP growth and future labor income growth respectively as the state variables. Jagannathan and Wang (1996) suggested a conditional CAPM, which is different from typical conditional models and does not depend on instrumental variables.

Although the extant literature suggests a number of alternative methods of estimating beta and return, the single index CAPM model is still the most theoretically sound and practically appealing approach of them. It is a core construct of modern finance. The CAPM relies on a number of explicit/implicit assumptions about investors and their opportunity set such as: (1) capital markets are perfect ${ }^{4}$; (2) all investors are single-period, risk averse maximisers of the expected utility of their terminal wealth; (3) they have access to unlimited borrowing and lending at a risk-free rate; (4) their best portfolio decisions are made solely on the basis of expected values (the means) and standard deviations of the probability

\footnotetext{
${ }^{4}$ In a perfect capital market (a) all agents are, individually, price-takers, (b) access is free (no transaction cost), and there is no 'friction' preventing the free trading of securities, (c) information has no cost and is available to all, (d) taxes are nonexistent (i.e. no external drains on wealth), and (e) capital assets are infinitely divisible.
} 
distributions of the returns on their portfolios (i.e. terminal wealth). This implies either that the investors' utility functions are quadratic or that the portfolio returns have a multivariate normal distribution; (5) they all have the same planning horizon, and over this period the mean and standard deviation of the probability distributions exist; and (6) they have homogeneous expectations with respect to the mean and standard deviation of each portfolio return distribution. Thus, the CAPM is operationalized based on some important assumptions such as homogeneous expectations of all investors about return, no transaction cost, large number of small investors and market equilibrium.

\subsection{Objective of the Study}

The primary objective of the study is to test the relationship between risks and returns in DSE both at individual security and portfolio levels. Using the CAPM beta as the measure of risk, the hypotheses being tested are:

$\mathrm{H}_{1}$ : There is a statistically significant positive beta (risk) for each individual securities/stocks listed in DSE, i.e. stock betas are positive and significantly different from zero.

$\mathrm{H}_{2}$ : There is a statistically significant linear relationship between beta and return of individual stocks in DSE, i.e. higher return is associated with a higher risk. The stock beta is significantly different from zero with positive risk premium.

$\mathrm{H}_{3}$ : There is a statistically significant linear relationship between portfolio beta and portfolio return in DSE, i.e. higher portfolio return is associated with commensurable higher risk.

\section{Data and Methodology}

The data set consists of monthly realized returns of 110 stocks included in the DSE General Index for the period January 2000 to December 2007. Monthly returns were used. The natural logarithmic differences in prices are used to measure the stock returns. The return is expressed in percentage form for ease of comparability. Symbolically, the returns have been expressed in percentage form as follows:

$$
R_{i t}=\operatorname{Ln}\left(\frac{p_{t}}{P_{t-1}}\right) * 100
$$

Where $R_{i t}$ is the return on stock $\mathrm{i}$ in time period $\mathrm{t}, \mathrm{P}_{\mathrm{t}}$ is monthly closing price of stock $\mathrm{i}$ and $\mathrm{P}_{\mathrm{t}-1}$ is the monthly opening price of stock $\mathrm{i}$. The market return was calculated as follows:

$X_{t}=\operatorname{Ln}\left(\frac{I_{t}}{I_{t-1}}\right) * 100$

Where $X_{t}$ is the return on the market index $\mathrm{I}_{\mathrm{t}}$ is the monthly closing number of market index and $\mathrm{I}_{\mathrm{t}-1}$ is the opening number of the market index.

The famous market model (CAPM) beta was used as the measure of risk and was estimated using the following regression model:

$E\left(R_{i t}\right)=\alpha_{i}+\beta_{i} X_{t}+e_{i t}$

Beta $(\beta)$ was estimated by regression of monthly security returns on the returns of the market index. 
Alpha $(\alpha)$ represents a constant intercept, indicating minimum level of return that is expected from security $i$, if the market remains flat.

Where $\alpha_{i}$ is the constant intercept of security i, $\beta_{i}$ is the slope (systematic risk) of security $\mathrm{i}$ and $e_{i t}$ is error term representing the residuals of security i. $e_{i t}$ represents non market (diversifiable) risk of security i.

Scholes and Williams (1977) and Dimson (1979) reported that the CAPM beta is biased upwards for frequently traded securities and downwards in case of thin trading. Literature suggests two or three types of alternative estimators to reduce the thin trading bias. Scholes and Williams (1977) suggested beta estimator accounts for non-trading that last at most for one period. Dimson (1979) proposed a multiple regression with leading and lagging market returns as additional regressors, where Dimson's beta is the sum of all these multiple coefficients. These two approaches are widely used (see for example, Mollah \& Mobarek, 2009 and Ward \& Muller 2012 for recent application in emerging market beta analysis). Another alternative is to measure returns at lower frequencies e.g., weekly holding-period returns rather than daily ones. The advantage of using the longer holding-period returns is that while the noise generated by thin trading is not affected, the true returns become larger, implying a better signal-to-noise ratio (see e.g., Stoll \& Whaley, 1990). We hope that our estimates of betas using lower frequency (longer holding-period) monthly returns are reasonably free from thin trading bias that existed in DSE. Also, thin trading may be unrelated to the risk-return relationship (Iqbal \& Brooks, 2007). We also tested the Dimson beta, with no improvement in results, therefore not reported.

\section{Results and Discussion}

\subsection{Risk-Return Relationship for Individual Securities: Characteristics Line}

The statistical summary of risk and return measures for all the stocks in terms of SIM are provided in Appendix A. Out of 110 securities, 58 have statistically significant beta at 1 percent significance level, 12 have beta significance at 5 percent level, and 16 have beta significance at 10 percent significance level. This means that the market wields a relevant influence on an individual stock's performance and beta is a good measure of risk in DSE. We can therefore reject the null hypothesis that there is no relationship between individual stocks' risk and return. Out of 110 securities, 8 securities have beta value exceeding market beta value of 1 , and 9 securities have negative beta values. The remaining securities have beta values between 0 and 1 .

Table 1 shows the risk-return matrix for 110 securities. When classified in terms of mean risk $(0.519)$ and mean return $(0.679 \%), 34$ securities belong to the high risk and high return class, 19 securities belong to the high risk and low return category, 17 securities lie in low risk and high return class while the residual 40 securities constitute the low risk and low return group. When classified in terms of market risk and market return, 4 securities fall under high risk and high return class, 4 securities belong to the high risk low return class, 11 securities lie in low risk high return class, while 91 securities are classed as representing the low risk and low return subset. 
Table 1: Risk-Return Matrix

\begin{tabular}{|c|c|c|c|c|}
\hline & & \multicolumn{2}{|c|}{$\begin{array}{c}\text { Based on Mean Security Return } \\
\text { Mean }=0.68\end{array}$} & \\
\hline & & High & Low & Total \\
\hline \multirow{5}{*}{$\begin{array}{l}\text { Based on Mean } \\
\text { Security Risk (Beta) } \\
\text { Mean }=0.52\end{array}$} & High & 34 & 19 & 53 \\
\hline & Low & 17 & 40 & 57 \\
\hline & Total & 51 & 59 & 110 \\
\hline & & \multicolumn{2}{|c|}{ Based on Market index return $=1.93$} & \\
\hline & & High & Low & Total \\
\hline \multirow{3}{*}{$\begin{array}{l}\text { Based on Market Risk } \\
(\text { Beta })=1\end{array}$} & High & 4 & 4 & 8 \\
\hline & Low & 11 & 91 & 102 \\
\hline & Total & 15 & 95 & 110 \\
\hline
\end{tabular}

Spearman's correlation coefficient value of 0.614 between beta values and expected return of individual securities and 0.544 between total market risk and expected return of individual securities indicate a high degree of relationship. However, Spearman's correlation coefficient between non-market idiosyncratic risks and expected return of individual securities is merely 0.011 and is not statistically significant even at 10 percent level. These correlation coefficients between measures of risk and expected return of individual securities support the proposition of the single index model that high risk yields high return and low risk yields low return. Figure 1 plots the expected returns of individual securities against their beta.

Figure 1: Relationship between beta and expected return of individual securities

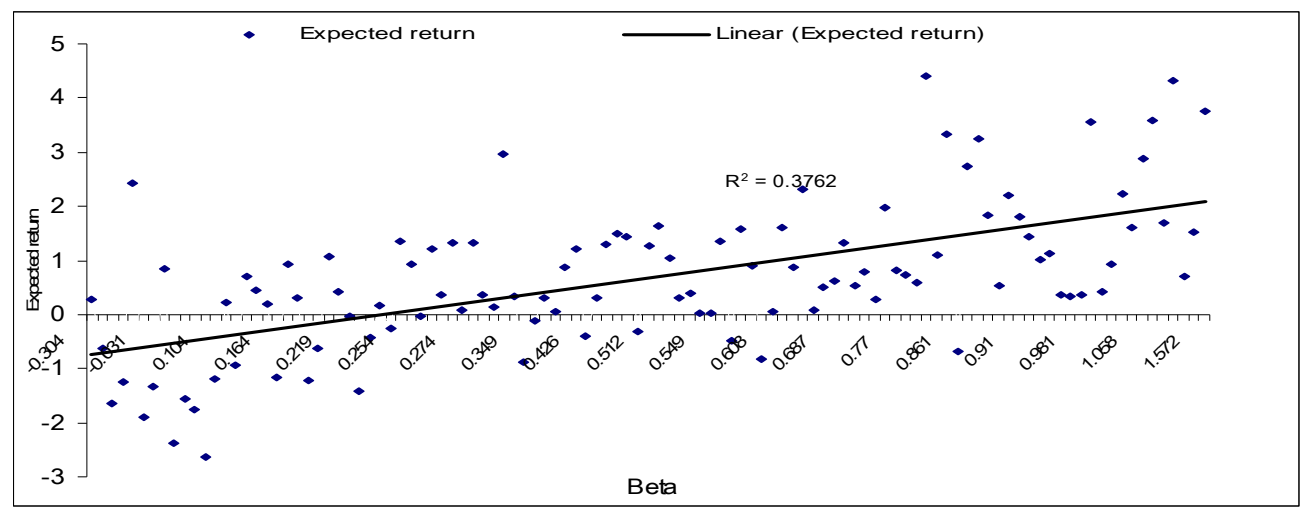

Table 2 depicts the summary statistics of the different variables used in the analysis to demonstrate the risk-return relationship concerning different securities. Coefficient of determination $\left(\mathrm{R}^{2}\right)$, which measures how much variation in stock return is explained by variation in index return, has the highest value of .473 , while the lowest $R^{2}$ is close to 0 for number of securities. Average $\mathrm{R}^{2}$ is 12.6 percent. This lower level of average coefficient of determination runs counter to the findings of Morck et al. (2000), who found that stocks tend to have large coefficients of determination $\left(\mathrm{R}^{2}\right)$ using a market model in emerging markets. Among the 110 stocks the highest beta is 1.572 and the lowest beta is -0.304 with the range 
Mollik \& Khokan Bepari | Risk-Return Trade-off in Emerging Markets: Evidence from DSE

of the beta being 1.876. The average beta is 0.519 . The highest expected return is 4.405 percent and the lowest expected return is -2.628 percent with a range being 7.033 percent. The average expected return is 0.679 percent. Similar variations are also evident in summary statistics of all other variables (Table 2).

Table 2: Summary statistics of risk-return relationship data of individual securities

\begin{tabular}{|l|l|l|l|l|l|l|l|l|}
\hline Summary statistics & Variance $_{\mathrm{st}}$ & $\mathrm{B}_{\mathrm{i}}$ & $\alpha$ & $\mathrm{B}_{\mathrm{i}}{ }^{2} \sigma_{\mathrm{x}} \mathrm{e}_{\mathrm{i}}{ }^{2}$ & $\beta_{\mathrm{SE}}$ & $\mathrm{R}^{2}$ & $\begin{array}{l}\text { Expected } \\
\text { return }\end{array}$ \\
\hline Mean & 171.65 & 0.51 & -0.33 & 17.00 & 155.23 & 0.18 & 0.13 & 0.68 \\
\hline Standard Deviation & 216.99 & 0.37 & 1.07 & 20.04 & 209.50 & 0.07 & 0.12 & 1.36 \\
\hline Sample Variance & 47088.14 & 0.13 & 1.16 & 401.92 & 43894.07 & 0.01 & 0.01 & 1.84 \\
\hline Kurtosis & 53.55 & -0.35 & 0.33 & 4.95 & 50.87 & 19.14 & -0.34 & 0.58 \\
\hline Skewness & 6.71 & 0.28 & 0.50 & 1.89 & 6.55 & 3.58 & 0.78 & 0.32 \\
\hline Minimum & 10.42 & -0.30 & -2.79 & 0.00 & 10.19 & 0.07 & 0.00 & -2.63 \\
\hline Maximum & 2041.43 & 1.57 & 2.83 & 108.93 & 1932.50 & 0.69 & 0.47 & 4.41 \\
\hline Range & 2031.01 & 1.87 & 5.62 & 108.93 & 1922.31 & 0.62 & 0.47 & 7.03 \\
\hline Observation & 110 & 110 & 110 & 110 & 110 & 110 & 110 & 110 \\
\hline
\end{tabular}

To test the linear risk-return relationship, a cross-sectional regression of an individual security's return on its beta ( $\beta$ ) estimate is carried out. Lintner (1965), Douglas (1969), and Fama and MacBeth (1973) suggested that the residual variance in the first stage regression may have additional explanatory power describing the return (dependent variable) in the second pass regression. Taking their suggestion into account, this study performed a crosssectional regression that included the $\log$ of residual variance as an additional independent variable along with beta $(\beta)$. The results from these regressions are reported in Table 3.

The evidence in Table 3 shows that individual securities beta $(\beta)$ values are significantly positively related to returns in all four regression models. Hence there exists a significant relationship between market risk and return in DSE. The coefficients of betasquare are not statistically significant in any of the two models. Values in the parentheses are the t-values calculated based on White's corrected standard errors. It has been found that White's correction does not significantly change the results. So, the results confirm that beta is linearly positively related to returns. When the log residual variance is added as an independent variable with beta $(\beta)$, and beta-square $\left(\beta^{2}\right)$, its coefficient becomes statistically significant, but the explanatory power of the model increases only marginally $\left(\mathrm{R}^{2}\right.$ increases from 0.42 to 0.43 and adjusted $R^{2}$ increases from 0.41 to 0.43 ). Therefore residual variance from the first stage regression or the firm-specific idiosyncratic risk has only little explanatory power of individual securities return.

Table 3, Panel A depicts the results of risk-return relationships when the sample companies are grouped based on beta (high and low beta), beta-return (high-beta-high-return and low-beta-low-return, high-return and low return and so on. It can be seen that all the coefficients of beta are statistically significant at $1 \%$ to $5 \%$ level of significance, except two un-usual cases where companies having high betas have low returns and having low betas have high returns. The results are logical and confirm the positive risk-return relationship reported above. Table 3, Panel B reports the results of the same models as in Panel A, but 
with beta-square $\left(\beta^{2}\right)$ as an additional independent variable to test the non-linearity of beta with returns. Beta is found to be significantly positively related to returns in the models of high-beta, high-beta-high-return, high-beta-low-return and low returns. In high-beta-lowreturn group the result of positive coefficient does not logically fit, can be disregarded. However, beta-square has been found to be significantly positively related to returns of low beta, low-beta-low-return and low-beta-high return groups, suggesting that in low-beta portfolios may have non-linear risk-return relationships. This is an interesting new finding which needs to be confirmed by further research.

Table 3: Cross-sectional regression results of individual security return on $\beta$ and $\log$ of residual variance

\begin{tabular}{|c|c|c|c|c|c|c|}
\hline Models & Constant & $\begin{array}{l}\text { Beta } \\
(\beta)\end{array}$ & $\begin{array}{l}\left(\beta^{2}\right) \\
\text { (Non- } \\
\text { linearity) }\end{array}$ & $\begin{array}{l}\text { Log } \\
\text { Residual } \\
\text { variance }\end{array}$ & $\mathrm{R}^{2}$ & Adjusted $\mathrm{R}^{2}$ \\
\hline $\begin{array}{l}\text { 1. Without } \beta^{2} \text { and } \\
\text { Residual Variance }\end{array}$ & $\begin{array}{l}-0.48^{*} \\
(-2.70)\end{array}$ & $\begin{array}{l}2.24^{*} \\
(6.93)\end{array}$ & - & - & 0.37 & 0.37 \\
\hline 2. With $\beta^{2}$ & $\begin{array}{l}-0.49^{* *} \\
(-1.92)\end{array}$ & $\begin{array}{l}2.28^{*} \\
2.67\end{array}$ & $\begin{array}{l}-0.04 \\
(-0.06)\end{array}$ & - & 0.37 & 0.36 \\
\hline $\begin{array}{l}\text { 3. With Log Residual } \\
\text { Variance }\end{array}$ & $\begin{array}{l}-1.58^{* *} \\
(-1.05) \\
\end{array}$ & $\begin{array}{l}2.31^{*} \\
(6.95)\end{array}$ & & $\begin{array}{l}-0.44 \\
(-2.92) \\
\end{array}$ & 0.42 & 0.41 \\
\hline $\begin{array}{l}\text { 4. With } \beta^{2} \text { and Log } \\
\text { Residual Variance }\end{array}$ & $\begin{array}{l}1.91^{*} \\
(2.72)\end{array}$ & $\begin{array}{l}1.63^{* *} \\
(1.93)\end{array}$ & $\begin{array}{l}0.60 \\
(0.77)\end{array}$ & $\begin{array}{l}-0.49^{*} \\
(-3.54)\end{array}$ & 0.43 & 0.42 \\
\hline & & $\begin{array}{r}\text { Panel A } \\
\mathrm{R}_{\mathrm{i}}=\alpha_{0}+\alpha_{1}\end{array}$ & $\begin{array}{l}\text { A } \\
{ }_{4} \beta_{i}+e\end{array}$ & & & \\
\hline Beta-return category & $\begin{array}{r}\mathrm{B} \\
\text { relati } \\
\end{array}$ & $\begin{array}{l}\text { ta-return } \\
\text { ship (linear) } \\
\beta_{\mathrm{i}}\end{array}$ & $\begin{array}{r}\mathrm{B} \\
\text { relati } \\
1\end{array}$ & $\begin{array}{l}\text { eta- return } \\
\text { ionship (non- } \\
\text { linear) } \beta^{2}\end{array}$ & & $\begin{array}{l}\text { sted R } \\
\text { e }\end{array}$ \\
\hline High beta & & $2.61 *$ & & $\mathrm{n} / \mathrm{a}$ & & .21 \\
\hline Low beta & & $2.70^{*}$ & & $\mathrm{n} / \mathrm{a}$ & & .18 \\
\hline Highbeta - high -return & & $.69^{* *}$ & & $\mathrm{n} / \mathrm{a}$ & & .11 \\
\hline High -beta - low -return & & 0.77 & & $\mathrm{n} / \mathrm{a}$ & & .04 \\
\hline Low -beta - low -return & & $1.90^{*}$ & & $\mathrm{n} / \mathrm{a}$ & & 0.14 \\
\hline Low -beta - high -return & & 0.09 & & $\mathrm{n} / \mathrm{a}$ & & -.07 \\
\hline High return & & $1.13^{*}$ & & $\mathrm{n} / \mathrm{a}$ & & .15 \\
\hline Low return & & $1.25^{*}$ & & $\mathrm{n} / \mathrm{a}$ & & .28 \\
\hline & & $\begin{array}{r}\text { Panel B } \\
R_{\mathrm{i}}=\alpha_{0}+\alpha_{1} \beta_{\mathrm{i}}+\end{array}$ & $\begin{array}{l}\mathrm{B} \\
+\alpha_{2} \beta_{\mathrm{i}}^{2}+e\end{array}$ & & & \\
\hline High beta & & $5.06^{*}$ & & -1.31 & & .20 \\
\hline Low beta & & 1.29 & & $4.71 * *$ & & .21 \\
\hline High -beta - high -return & & $5.13 *$ & & -1.72 & & .10 \\
\hline High -beta - low -return & & $3.46^{*}$ & & -1.78 & & -.02 \\
\hline Low -beta - low -return & & 0.76 & & $5.74 * *$ & & .22 \\
\hline Low -beta - high -return & & -1.29 & & $2.63 * *$ & & -.12 \\
\hline High return & & 0.31 & & 0.59 & & .15 \\
\hline Low return & & $1.40^{*}$ & & -0.19 & & .26 \\
\hline
\end{tabular}

Figures in the parenthesis indicate t-ratios (White's corrected); * Significant at $1 \%$ level, **Significant at 5\% level 
Mollik \& Khokan Bepari | Risk-Return Trade-off in Emerging Markets: Evidence from DSE

\subsection{Relationship between Portfolio Return and Risk}

Following Sharpe and Cooper (1972), Amanulla and Kamaiah (1998) and Dhankar and Kumar (2006), we construct 11 portfolios of 10 securities each on the basis of beta values of 110 individual stocks. Portfolios with high betas can be considered as high risk-return class while portfolios with low betas are low risk return class (Sharpe \& Cooper, 1972). We construct portfolios consisting of stocks in descending order of their beta values. The total number of companies are arranged in descending order of beta and grouped into 11 portfolios of 10 securities each. This is done to achieve the diversification required to reduce effect of unique risk as done in above studies. Table 4 reports the summary statistics for portfolio risk and returns. The beta values of 10 out of 11 portfolios are significant at 1 percent level. The remaining one is significant at 5\% level of significance, suggesting a close relationship between portfolio risk and returns. Spearman's correlation coefficient between portfolio beta and portfolio expected return is found to be 0.938 , while the correlation coefficient between portfolio market risk and portfolio expected return is 0.887 . Both the coefficients are significant at 5 percent level of significance. Risk measures (i.e. total risk, total market risk and beta) of portfolios indicate consistency in all cases as one moves from a high beta portfolio to a low beta portfolio. Although not consistent in all cases, $\mathrm{R}^{2}$ (coefficient of determination) is demonstrating an overall declining trend in the portfolio beta values and market risks.

Table 4: DSE Portfolio returns and risks

\begin{tabular}{|c|c|c|c|c|c|c|c|c|c|c|c|}
\hline Portfolio & $\begin{array}{l}\text { No. of } \\
\text { Stock }\end{array}$ & Var & $\beta_{p}$ & $a$ & $\beta_{p}^{2} \sigma_{x}^{2}$ & $\sigma_{e p}^{2}$ & $\beta_{\mathrm{SE}}$ & $\mathrm{R}^{2}$ & $E\left(R_{P}\right)$ & $\begin{array}{l}\text { Return per } \\
\text { unit of } \\
\text { market risk }\end{array}$ & $\begin{array}{l}\text { Return per } \\
\text { unit of } \\
\text { total risk }\end{array}$ \\
\hline P1 & 10 & 92.87 & $1.17^{*}$ & 0.03 & 60.18 & 32.69 & 0.24 & 0.65 & 2.28 & 0.04 & 0.03 \\
\hline P2 & 10 & 51.62 & $0.95^{*}$ & -0.56 & 39.46 & 12.15 & 0.17 & 0.77 & 1.27 & 0.03 & 0.03 \\
\hline P3 & 10 & 48.44 & $0.85^{*}$ & 0.18 & 31.52 & 16.92 & 0.19 & 0.65 & 1.80 & 0.06 & 0.04 \\
\hline P4 & 10 & 32.21 & $0.72^{*}$ & $\begin{array}{l}-0.60 \\
\end{array}$ & 22.55 & 9.66 & 0.15 & 0.70 & 0.78 & 0.04 & 0.02 \\
\hline P5 & 10 & 28.42 & $0.59^{*}$ & -0.49 & 15.51 & 12.92 & 0.17 & 0.55 & 0.65 & 0.04 & 0.02 \\
\hline P6 & 10 & 20.42 & $0.50^{*}$ & -0.06 & 10.99 & 9.43 & 0.15 & 0.54 & 0.90 & 0.08 & 0.04 \\
\hline P7 & 10 & 16.05 & $0.37 *$ & -0.26 & 5.95 & 10.10 & 0.15 & 0.37 & 0.45 & 0.08 & 0.03 \\
\hline P8 & 10 & 14.59 & $0.27^{*}$ & 0.05 & 3.23 & 11.37 & 0.16 & 0.22 & 0.57 & 0.18 & 0.04 \\
\hline P9 & 10 & 14.27 & $0.21 *$ & -0.46 & 1.91 & 12.36 & 0.17 & 0.13 & -0.06 & -0.03 & 0.00 \\
\hline P10 & 10 & 18.30 & $0.11^{*}$ & -0.98 & 0.56 & 17.74 & 0.20 & 0.03 & $\begin{array}{l}-0.77 \\
\end{array}$ & $\begin{array}{l}-1.38 \\
\end{array}$ & $\begin{array}{l}-0.04 \\
\end{array}$ \\
\hline P11 & 10 & 24.08 & $-0.08 * *$ & -0.47 & 0.22 & 23.87 & 0.26 & 0.01 & -0.56 & -2.61 & -0.02 \\
\hline Average & & 32.84 & 0.51 & -0.33 & 17.90 & 15.38 & 0.18 & 0.42 & 0.66 & -0.32 & 0.02 \\
\hline \multirow{2}{*}{\multicolumn{3}{|c|}{$\begin{array}{l}\text { Spearman Correlation } \\
\text { Coeffient }\end{array}$}} & \multicolumn{9}{|c|}{ Between portfolio beta \& portfolio expected return } \\
\hline & & & \multicolumn{9}{|c|}{ Between portfolio market risk \& portfolio expected return $\quad 0.89^{*}$} \\
\hline
\end{tabular}

*Significant at $1 \%$ level; ${ }^{*}$ Significant at $5 \%$ level; $\mathrm{R}^{2}$ equals market risk divided by total risk

Table 5: Risk-Return Matrix of portfolio of securities

\begin{tabular}{|c|c|c|c|c|}
\hline & & \multicolumn{2}{|c|}{$\begin{array}{c}\text { Based on Mean Security Return } \\
\text { Mean }=0.66\end{array}$} & \\
\hline & & High & Low & Total \\
\hline \multirow{5}{*}{$\begin{array}{l}\text { Based on Mean } \\
\text { Security Risk (Beta) } \\
\text { Mean=0.51 }\end{array}$} & High & 4 & 1 & 5 \\
\hline & Low & 1 & 5 & 6 \\
\hline & Total & 5 & 6 & 11 \\
\hline & & \multicolumn{2}{|c|}{ Based on Market index return $=1.93$} & \\
\hline & & High & Low & Total \\
\hline \multirow{3}{*}{$\begin{array}{l}\text { Based on Market Risk } \\
(\text { Beta })=1\end{array}$} & High & 1 & 0 & 1 \\
\hline & Low & 0 & 10 & 10 \\
\hline & Total & 1 & 10 & 11 \\
\hline
\end{tabular}


It is evident in Table 5 that an investor can choose from these 11 portfolios with different levels of risk and expected return with risk and return having a positive relationship in that high risk yield high expected a return and vice versa. However, in Table 4 relative measures in terms of return per unit of total risk and return per unit of market risk are not showing consistency. P8 offers the highest return per unit of market risk and for this reason a conservative investor will choose this portfolio. On the other hand P1 provides the highest return in absolute terms although it is not offering the highest return in relative terms. It is expected that the portfolio with high beta will be associated with high return and low beta with low return. This systemic pricing pattern is not observed across all the portfolios in Table 4. Hence we conclude that although portfolio risk and return in DSE are positively linearly related in general, higher risk does not always offer higher return, indicating that market anomalies exist. This implies that investors will have to search for efficient portfolios to maximize return for a given level of risk in DSE.

As noted in the portfolio theory, the error term in the first stage regression refers to security-specific risk and this can be avoided by combining securities in one portfolio. Thus portfolio return will be linearly and positively related to portfolio beta. Pursuing this line the present study regress the portfolio returns on portfolio beta. Portfolio return is also regressed on portfolio beta and portfolio residual variance in the log form. The results are reported in Table 6.

Table 6: Cross-sectional regression results of portfolio return on $\beta$ and $\log$ residual variance

\begin{tabular}{|c|l|l|l|l|l|}
\hline & Constant & Beta $(\beta)$ & $\begin{array}{l}\text { Residual } \\
\text { variance }\end{array}$ & $\mathrm{R}^{2}$ & Adjusted $\mathrm{R}^{2}$ \\
\hline Without residual variance & $-0.50^{* *}$ & $\begin{array}{l}2.26^{*} \\
(-2.79)\end{array}$ & - & 0.88 & 0.86 \\
\hline With log residual variance & -0.64 & $\begin{array}{l}2.25^{*} \\
(7.47)\end{array}$ & $\begin{array}{l}0.13 \\
(0.85)\end{array}$ & 0.88 & 0.85 \\
& $(-0.83)$ & $(0.4)$ & \\
\hline
\end{tabular}

Figures in the parenthesis are t-ratios; * Significant at $1 \%$ level, **Significant at $5 \%$ level

Table 6 supports a highly positive linear relationship between portfolio beta and portfolio return. While the coefficient of beta is statistically significant at $1 \%$ level of significance, the coefficient of the log of residual variance is not statistically significant even at 10 percent level. Thus portfolio non-market risk is not relevant for portfolio return.

\subsection{Empirical Security Market Line (SML)}

An efficient market provides rewards for risk. High return is associated with high risk and low return with low risk. The security market line helps to determine the required level of return for a given level of risk. Figure 2 depicts the observed security market line (SML) which has been constructed to demonstrate the relationship between portfolio expected return and portfolio beta. 
Figure 2: Relationship between portfolio beta and portfolio expected return

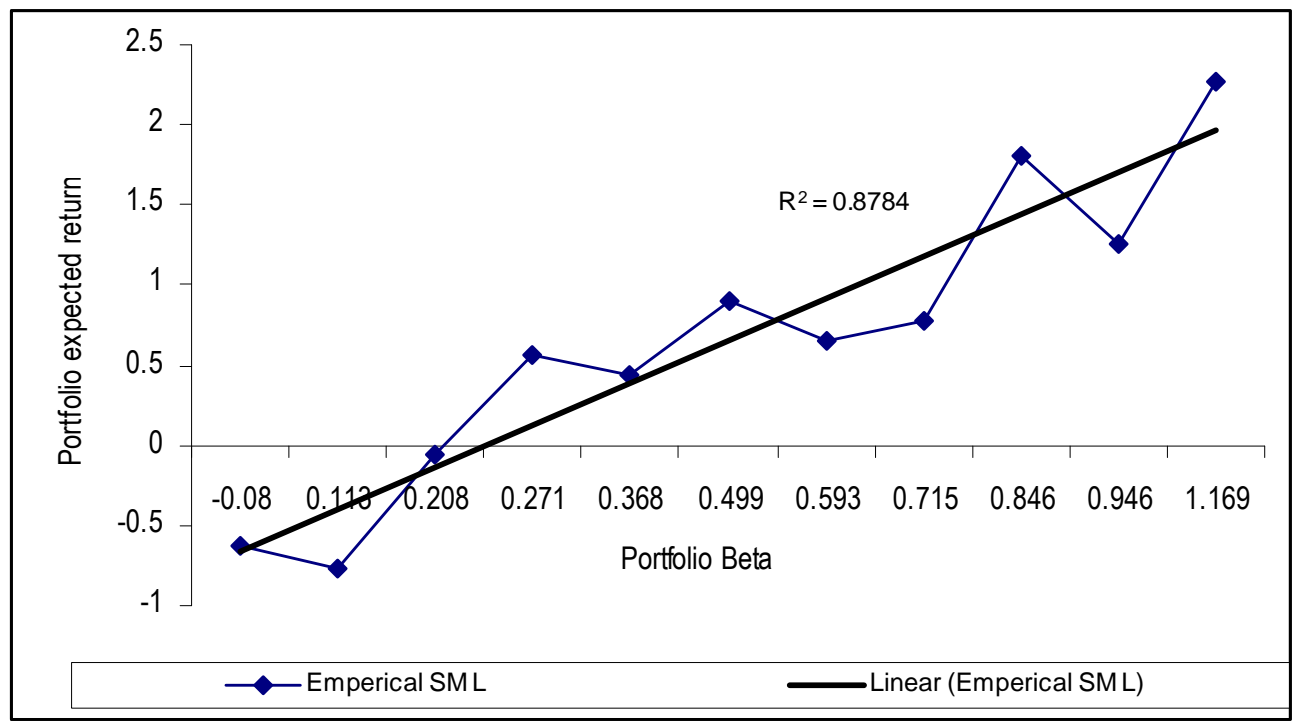

There seems to be a highly positive and linear relationship between portfolio expected return and portfolio market risk, which validates the efficient market hypothesis in DSE in that investors earn high expected return by investing in high beta portfolios in general, and vice versa (theoretically incorrect statement). However, the deviation of empirical SML from linear SML implies that there are mispriced stocks (portfolio), some under-valued and some over-valued, in the DSE.

\section{Conclusion}

This paper investigates the risk-return relationship of both individual securities and portfolio of securities and the effect of diversification on non-market risk of portfolios in DSE, Bangladesh, using the DSE Single Index Model. Security returns exhibit statistically significant positive movements in tandem with market movements. Portfolio risks and returns are also highly positively related in that portfolio beta values are statistically significant in the portfolio risk-return models. The results also reveal that when companies are grouped based on betas (high and low betas) and beta-returns (high-beta-high-return and low-beta-lowreturn and son), the groups with low betas have statistically significant non-linear beta-return relationships. However, the highest beta assets are not always associated with the highest return, suggesting the existence of market anomalies. These findings validate the efficient market hypothesis in DSE in terms of risk-return trade-off in general, which have important implications for investment decisions. Investors should hold efficiently diversified portfolios to maximize their return for a particular level of risk because they will be rewarded only for systematic risk.

The findings of the study are limited to the use of standard mean-variance CAPM model. Further studies, using other multi-variate asset pricing models e.g., AP, Fama-French Three-factor to Five-factor models can reconfirm the findings in DSE and other emerging markets. Since we have used low frequency monthly data, future studies using higher frequency (i.e., daily or weekly) data for a longer period can be attempted to revalidate the 
findings in emerging markets, including DSE. The non-linearity of beta in low beta assets classes is a new finding, which needs to be supported by further rigorous research in the area.

\section{REFERENCES}

Alam, M. M., Alam, K. A. and Uddin, M. G. S., (2007), Market Depth and Risk Return Analysis for Dhaka Stock Exchange: An Empirical Test of Market Efficiency. ASA University Review, 1(1), pp. 93-101.

Ali, M. H., Islam, S. and Chowdhury, M. M., (2010), Test of CAPM in Emerging Stock Markets: A study on Dhaka Stock Exchange, The Cost and Management, NovemberDecember, pp. $34-37$.

Amanulla, S. and Kamaiah, B., (1998). Asset price behaviour in Indian stock market: Is the CAPM still relevant. Journal of Financial Management and Analysis, 11(1), pp. 32-47.

Bali, T.G. and Peng, L., (2006). Is there a risk-return trade-off? Evidence from high frequency data. Journal of Applied Econometrics, 21, pp. 1169-1198. DOI: http://dx.doi.org/10.1002/jae.911

Bali, T.G., Demirtas, K. and Levy, H., (2009). Is there an intertermporal relation between downside risk and expected returns? Journal of Financial and Quantitative Analysis, 44, pp. 883-909. DOI: http://dx.doi.org/10.1017/S0022109009990159

Bark, T., (1991). Anti-dumping Restrictions against Korean Exports: Major Focus on Consumer Electronics Products. Korean Institute for International Economic Policy (May) No. 91-02.

Bartholdy, J. and Peare, P., (2005). Estimation of expected return: CAPM vs. Fama and French. International Review of Financial Analysis, 14(4), pp. 407-427. DOI: http://dx.doi.org/10.1016/j.irfa.2004.10.009

Bepari, M.K., and Mollik, A., (2008). Bangladesh stock market growing? Key indicators based assessment. Journal of Business Administration Online, 7(2), available at www.atu.edu/business/jbao/.

Black, F., (1972). Capital Market Equilibrium with Restricted Borrowing. Journal of Business. 45(3), pp. 444-454. DOI: http://dx.doi.org/10.1086/295472

Breeden, D., (1979). An intertemporal asset pricing model with stochastic consumption and investment opportunities. Journal of Financial Economics 7, pp. 265-296.

Bruner, F., Eades, K., Harris, R. and Higgins, R., (1998). Best practices in estimating the cost of capital: Survey and synthesis. Financial Practice and Education, 8(1), pp. 1328.

Campbell, J.Y., (1996). Understanding risk and return. Journal of Political Economy, 104, pp. 298-345. DOI: http://dx.doi.org/10.1086/262026

Chen, L., Novy-Marx, R., Zhang, L., (2010). An Alternative Three-factor Model. Working paper.

Cheung, Y.L., Wong, A. and Ho, K.Y., (1993). The pricing of risky assets in two emerging Asian markets-Korea and Taiwan. Applied Financial Economics, 3(4), pp. 315-24. DOI: http://dx.doi.org/10.1080/758534943

Cheung, Y.L. and Wong, K.T., (1992). An Assessment of Risk and Return: Some Empirical Findings from Hong Kong stock Exchange. Applied Financial Economics, 3, pp. 315-324. DOI: http://dx.doi.org/10.1080/758534943

Claessens, S., Dasgupta, S. and Glen, J., (1995). Return Behavior in Emerging Stock Markets. World Bank Economic Review, 9(1), pp. 131-151. DOI: http://dx.doi.org/10.1093/wber/9.1.131 
Mollik \& Khokan Bepari | Risk-Return Trade-off in Emerging Markets: Evidence from DSE

Darrat, A.F., Gilley, O.W., Li, B. and Wu, Y., (2011). Revisiting the risk/return relations in the Asian Pacific markets: New evidence from alternative models. Journal of Business Research, 64, pp.199-206.

DOI: http://dx.doi.org/10.1016/j.jbusres.2010.02.008

Dhankar, R.S. and Kumar, R., (2006). Risk-return relationship and effect of diversification on non-market risk: application of market index model in Indian stock market. Journal of Financial Management and Analysis, 19(2), pp. 22-31.

Dimson, E.,(1979). Risk Measurement When Shares are Subject to Infrequent Trading. Journal of Financial Economics, 6, pp.197-226. DOI: http://dx.doi.org/10.1016/0304$\underline{405 X(79) 90013-8}$

Douglas, G.M., (1969). Risk in the Equity Markets: An Empirical Appraisal of Market Efficieny. Yale Economic Essay, 9, pp. 3-45.

Estrada, J., (2000). The cost of equity in emerging markets: A downside risk approach. Emerging Markets Quarterly, 4, pp. 19-30.

Fama, E.F. and MacBeth, J., (1973). Risk return and equilibrium: Empirical tests. Journal of Political Economy, 81(3), pp. 607-636. DOI: http://dx.doi.org/10.1086/260061

Fama E.F. and French K., (2004). The Capital Asset Pricing Model: Theory and Evidence. Journal of Economic Perspective, 18, pp. 25-46. DOI: http://dx.doi.org/10.1257/0895330042162430

Fama, E. F.and French, K. R., (1992). Cross-section of Expected Stock Returns. Journal of Finance, 47, pp. 427-463.

DOI: http://dx.doi.org/10.1111/j.1540-6261.1992.tb04398.x

Fama, E.F. French, K.R., (1993). Common risk factors in the returns on bonds and stocks. Journal of Financial Economics, 33, pp. 3-56. DOI: http://dx.doi.org/10.1016/0304405X(93)90023-5

Fama, E.F. French, K.R., (1996). Multifactor explanations of asset pricing anomalies. Journal of Finance, 51, pp. 55-84. DOI: http://dx.doi.org/10.1111/j.15406261.1996.tb05202.x

Focardi, F. M. and Fabozzi, F. J., (2004). The Mathematics of Financial Modeling and Investment Management, John-Wiley \& Sons, Hoboken: New Jersey

Faruque, M., (2012). An Empirical Investigation of the Arbitrage Pricing Theory in a Frontier Stock Market: Evidence from Bangladesh, MPRA Munich Personal RePEc Archive, Online at http://mpra.ub.uni-muenchen.de/38675/MPRA Paper No.38675, May 2012, UTC

Ghysels, E., Santa-Clara, P. and Valkanov, R., (2005). There is a risk-return trade-off after all. Journal of Financial Economics, 76, pp. 509-548. DOI: http://dx.doi.org/10.1016/j.jfineco.2004.03.008

Glosten, L.R., Jagannathan, R. and Runkle, D.E., (1993). On the relation between expected value and the volatility of the nominal excess return on stocks. Journal of Finance, 48, pp. 1779-1801. DOI: http://dx.doi.org/10.1111/j.15406261.1993.tb05128.x

Goyal, A. and Santa-Clara, P., (2003). Idiosyncratic risk matters! Journal of Finance, 58, pp. 975-1007. DOI: http://dx.doi.org/10.1111/1540-6261.00555

Graham, J.R. and Harvey, C.R., (2001). The theory and practice of corporate finance: evidence from the field. Journal of Financial Economic, 60, pp. 187-243. DOI: http://dx.doi.org/10.1016/S0304-405X(01)00044-7

Guy, J. R. F., (1977). The Behavior of Equity Securities on the German Stock Exchange. Journal of Banking and Finance, 1, pp. 71-93. DOI: http://dx.doi.org/10.1016/03784266(77)90019-X 
Hasan, M. Z., Kamil, A. A., Mustafa, A. and Baten, M. A., (2011). A Validity test of Capital Asset Pricing Model for Dhaka Stock Exchange. Journal of Applied Sciences, 11(20), pp. 3490 - 3496. DOI: http://dx.doi.org/10.3923/jas.2011.3490.3496

Harvey, C., (1995). Predictable risk and returns in emerging markets. Review of Financial Studies, 8, pp. 773-816. DOI: http://dx.doi.org/10.1093/rfs/8.3.773

Harvey, C., (1995a). The cross-section of volatility and autocorrelation in emerging markets. Finanzmarket and Portfolio Management, 9, pp. 12-34.

Harvey, C., (1995b). The risk exposure of emerging equity markets. World Bank Economic Review, 9(1), pp. 19-50. DOI: http://dx.doi.org/10.1093/wber/9.1.19

Harvey, C., (2001). The specification of conditional expectations. Journal of Empirical Finance, 8, pp. 573-638. DOI: http://dx.doi.org/10.1016/S0927-5398(01)00036-6

Hawawini, G. A., and Michel, P. A., (1982). The Pricing of Risky Assets on the Belgian Stock Market. Journal of Banking and Finance, 6, pp. 161-178. DOI: http://dx.doi.org/10.1016/0378-4266(82)90031-0

Huang, Y. S., (1997). An empirical test of the risk-return relationship on the Taiwan Stock Exchange. Applied Financial Economics, 7, pp. 229-239. DOI: http://dx.doi.org/10.1080/096031097333583

Iqbal, J. and Brooks, R.D., (2007). Alternative beta risk estimators and asset pricing tests in emerging markets: the case of Pakistan. Journal of Multinational Financial Management, 17, pp. 75-93. DOI: http://dx.doi.org/10.1016/j.mulfin.2006.04.001

Jagnnathan, R. and McGrattan, E. R., (1995). The CAPM debate. Federal Reserve Bank of Minneapolis. Quarterly Review, 19(4), pp. 2-27.

Jegadeesh, N., (1992). Does market risk really explain the size effect? Journal of Financial and Quantitative Analysis, 10, pp. 337-351. DOI: http://dx.doi.org/10.2307/2331323

Jagannathan, R., Wang, Z., (1996). The conditional CAPM and the cross-section of expected returns. Journal of Finance, 51, pp. 3-54. DOI: http://dx.doi.org/10.1111/j.1540$\underline{6261.1996 . t b 05201 . x}$

Kim, D., (2006). On the information uncertainty risk and the January effect. Journal of Business, 79, pp. 2127-2162. DOI: http://dx.doi.org/10.1086/503659

Kim, D., Kim, T.-S., Min, B.-K., (2011). Future labor income growth and the cross-section of equity returns. Journal of Banking and Finance, 35, pp. 67-81. DOI: http://dx.doi.org/10.1016/j.jbankfin.2010.07.014

Lintner, J., (1965). Security prices, risk and maximum gains from diversification. Journal of Finance, 20, pp. 587-616.

Lucas, R., (1978). Asset prices in an exchange economy. Econometrica, 46, pp. 1429-1445. DOI: http://dx.doi.org/10.2307/1913837

Mandelker, G. and S. Rhee, (1984). The Impact of the Degrees of operating and Financial Leverage on Systematic Risk of Common Stocks. Journal of Financial and Quantitative Analysis, March, pp. 45-57. DOI: http://dx.doi.org/10.2307/2331000

Markowitz, H., (1952). Portfolio selection. Journal of Finance, 7, pp.77-91.

Merton, R.C., (1973). An Intertemporal Capital Asset Pricing Model. Econometrica, 41 (5), pp. 867-887.

Mollah, S. A. and Mobarek, A., (2009). Thin Trading, the Estimation of Beta and the Relationship between Share Return and Beta in the Emerging Market of Botswana, International Journal of Business Research, 9(1), pp. 119-125.

Morck, R., Yeung, B. and Yu, W., (2000). The information content of stock markets: Why do emerging markets have synchronous stock price movement? Journal of Financial Economics, 58, pp. 215-260. DOI:http://dx.doi.org/10.1016/S0304405X(00)00071-4 
Mollik \& Khokan Bepari | Risk-Return Trade-off in Emerging Markets: Evidence from DSE

Mollik, T.A. and Bepari, K.M., (2010). Instability of stock beta in Dhaka Stock Exchange.Bangladesh. Managerial Finance, 36 (10), pp. 886-902. DOI: http://dx.doi.org/10.1108/03074351011070251

Mossin, J., (1966). Equilibrium in a capital asset market. Econometrica, 34, pp.768-783. DOI: http://dx.doi.org/10.2307/1910098

Nawalkha, S. and Schwarz C., (2004). The progeny of CAPM. Available at SSRN: http://ssrn.com/abstract $=966403$.

Rahman, M.M. and Baten, M.A., (2006). An Empirical Testing of Capital Asset Pricing Model in Bangladesh. Journal of Research (Science), Bahauddin Zakariya University, Multan, Pakistan, 17(4), pp. 225-234.

Rubinstein, M., (1976). The valuation of uncertain income streams and the pricing of options. Bell Journal of Economics and Management Science, 7, pp. 407-425. DOI: http://dx.doi.org/10.2307/3003264

Ross, S.A., (1976). The arbitrage theory of capital asset pricing. Journal of Economic Theory, 13, pp. 341-360. DOI: http://dx.doi.org/10.1016/0022-0531(76)90046-6

Sauer, A., and Murphy, A., (1992). An Empirical Comparison of Alternative Models of Capital Asset Pricing in Germany. Journal of Banking and Finance, Vol. 16, pp. 183196.DOI: http://dx.doi.org/10.1016/0378-4266(92)90084-D

Scholes, M., and Williams, J., (1977). Estimating Betas from Nonsynchronous Data. Journal of Financial Economics. 5, pp. 309-327.DOI: http://dx.doi.org/10.1016/0304405X(77)90041-1

Sharpe, W.F., (1964). Capital asset prices: A theory of market equilibrium under conditions of risk. Journal of Finance, 19, pp. 425-442.

Sharpe, W.F. and Cooper, G.M., (1972). Risk-return classes of New York Stock Exchange common stocks, 1931-1967. Financial Analysts Journal, 28(2), pp. $\quad$ 46-54. DOI: http://dx.doi.org/10.2469/faj.v28.n2.46

Stoll, H. and Whaley, R., (1990). The Dynamics of Stock Index and Stock Index Futures Returns. Journal of Financial and Quantitative Analysis, 25, pp. 441-468. DOI: http://dx.doi.org/10.2307/2331010

Strugnell D, Gilbert E and Kruger R., ( 2011). Beta, Size and Value Effects on the JSE. Investment Analysts Journal, 74, pp. 1-17.

Vassalou, M., (2003). News related to future GDP growth as a risk factor in equity returns. Journal of Financial Economics, 68, pp. 47-73. DOI: http://dx.doi.org/10.1016/S0304-405X(02)00248-9

Ward, M. and Muller, C., (2012). Empirical testing of the CAPM on the JSE. Investment Anlaysts Journal, 76: 1 - 12.

Wolf, H.C., (1998). Determinants of Emerging Market Correlations in Emerging Market Capital Flows, R. M. Levich, Ed, Kluwer Academic Publishers, Boston. 
AABFJ | Volume 9, no. 1, 2015

Appendix A: Risk-return relationship of individual security

\begin{tabular}{|c|c|c|c|c|c|c|c|c|}
\hline $\begin{array}{l}\text { Company name [check } \\
\text { proper nouns in these } \\
\text { names] }\end{array}$ & Variance $_{\mathrm{st}}$ & $\beta_{i}$ & $\alpha$ & $\beta_{i}^{2} \sigma_{\mathrm{x}}^{2}$ & $\mathrm{e}_{\mathrm{i}}^{2}$ & $\beta_{\mathrm{SE}}$ & $\mathrm{R}^{2}$ & $\begin{array}{l}\text { Mean } \\
\text { return }\end{array}$ \\
\hline Rupali Bank ltd. & 2041.438 & $1.57 * *$ & 0.731 & 108.930 & 1932.508 & 0.687 & 0.053 & 3.758 \\
\hline NCCBL & 214.915 & $1.49 *$ & -1.321 & 97.506 & 117.409 & 0.167 & 0.473 & 1.512 \\
\hline Beximco Pharma & 149.464 & $1.20 *$ & -1.586 & 62.900 & 86.564 & 0.145 & 0.421 & 0.714 \\
\hline Uttara Bank & 246.434 & $1.13^{*}$ & 2.193 & 55.928 & 190.506 & 0.216 & 0.227 & 4.326 \\
\hline Sotuheast Bank & 191.036 & $1.12 *$ & -0.436 & 54.992 & 136.043 & 0.181 & 0.297 & 1.700 \\
\hline $\mathrm{AB}$ bank & 169.754 & $1.10^{*}$ & 1.459 & 53.726 & 116.028 & 0.168 & 0.316 & 3.585 \\
\hline Lafarge Surma Cement ltd. & 150.269 & $1.06^{*}$ & 0.299 & 49.348 & 100.921 & 0.189 & 0.411 & 2.875 \\
\hline Prime bank ltd. & 195.701 & $1.05^{*}$ & -0.402 & 48.402 & 147.299 & 0.190 & 0.247 & 1.616 \\
\hline Apex Food & 126.990 & $0.99 *$ & -0.985 & 43.111 & 83.880 & 0.143 & 0.339 & 0.919 \\
\hline Pubali bank ltd. & 400.675 & $0.99 *$ & 0.328 & 43.126 & 357.549 & 0.295 & 0.108 & 2.232 \\
\hline BD Lamps & 120.610 & $0.99 *$ & -1.492 & 42.898 & 77.712 & 0.138 & 0.356 & 0.407 \\
\hline Dutch Bangla Bank Ltd. & 210.062 & $0.98^{*}$ & 1.659 & 42.529 & 167.533 & 0.207 & 0.222 & 3.566 \\
\hline Heidelberg cement & 151.235 & $0.98 *$ & -1.522 & 1.170 & 150.065 & 0.163 & 0.280 & 0.367 \\
\hline Bangladesh General Ins. & 142.646 & $0.97 *$ & -1.523 & 41.676 & 101.269 & 0.157 & 0.290 & 0.343 \\
\hline Niloy cement & 206.325 & $0.95 *$ & -1.465 & 39.611 & 166.713 & 0.202 & 0.192 & 0.360 \\
\hline Olympic industries ltd. & 208.259 & $0.94 *$ & -0.648 & 38.863 & 169.396 & 0.203 & 0.187 & 1.124 \\
\hline Apex Tannery & 128.471 & $0.92 *$ & -0.325 & 37.365 & 91.107 & 0.149 & 0.291 & 1.448 \\
\hline Meghna cement & 127.618 & $0.92 *$ & -0.752 & 37.400 & 90.219 & 0.148 & 0.293 & 1.021 \\
\hline Square Pharma. & 140.671 & $0.91 *$ & 0.040 & 36.478 & 104.194 & 0.159 & 0.259 & 1.792 \\
\hline Usmania Glass & 133.304 & $0.90 *$ & 0.464 & 36.033 & 97.217 & 0.154 & 0.270 & 2.205 \\
\hline Singer Bangladesh Ltd. & 97.589 & $0.90 *$ & -1.190 & 35.522 & 62.067 & 0.123 & 0.364 & 0.538 \\
\hline The City bank ltd. & 221.344 & $0.89 *$ & 0.095 & 35.620 & 185.724 & 0.213 & 0.161 & 1.826 \\
\hline IFIC Bank & 236.437 & $0.88^{*}$ & 1.551 & 2.175 & 234.262 & 0.222 & 0.145 & 3.246 \\
\hline National life insurance & 120.702 & $0.86^{*}$ & 1.068 & 32.895 & 87.807 & 0.146 & 0.273 & 2.731 \\
\hline Shine Pukur Holdings Ltd. & 637.622 & $0.86^{* *}$ & -2.343 & 32.697 & 604.926 & 0.384 & 0.051 & -0.684 \\
\hline National Bank ltd. & 111.132 & $0.83 *$ & 1.740 & 30.666 & 80.466 & 0.140 & 0.276 & 3.345 \\
\hline Keya Cosmetics & 160.284 & $0.82 *$ & -0.264 & 29.524 & 130.760 & 0.187 & 0.210 & 1.094 \\
\hline UCBL & 149.130 & $0.82 *$ & 2.835 & 29.293 & 119.837 & 0.171 & 0.196 & 4.405 \\
\hline MiracleIndustries & 125.286 & $0.81 *$ & -0.963 & 29.203 & 96.083 & 0.153 & 0.233 & 0.604 \\
\hline Prime textile spinning mills & 116.730 & $0.78^{*}$ & -0.766 & 27.024 & 89.705 & 0.148 & 0.232 & 0.742 \\
\hline Green delta life insurance & 148.620 & $0.77 *$ & -0.669 & 26.137 & 122.482 & 0.173 & 0.176 & 0.813 \\
\hline ACI Ltd. & 67.552 & $0.76^{*}$ & 0.509 & 25.462 & 42.090 & 0.101 & 0.377 & 1.972 \\
\hline Janata insurance & 152.784 & $0.73^{*}$ & -1.133 & 23.666 & 129.188 & 0.177 & 0.155 & 0.278 \\
\hline Rupali Insurance Co. & 93.438 & $0.73 *$ & -0.622 & 23.645 & 69.793 & 0.130 & 0.253 & 0.788 \\
\hline Phoenix insurance ltd. & 114.468 & $0.72 *$ & -0.864 & 22.858 & 91.610 & 0.149 & 0.200 & 0.523 \\
\hline National tubes ltd. & 187.474 & $0.71^{*}$ & -0.038 & 22.246 & 165.228 & 0.201 & 0.119 & 1.330 \\
\hline Karnaphuly Insurance co. & 86.307 & $0.69 *$ & -0.697 & 20.784 & 65.523 & 0.126 & 0.241 & 0.625 \\
\hline Quasem drycell ltd. & 87.390 & $0.69 *$ & -0.799 & 20.655 & 66.734 & 0.128 & 0.236 & 0.519 \\
\hline United Leasing Co. Ltd. & 107.139 & $0.68 *$ & -1.231 & 20.375 & 149.765 & 0.191 & 0.120 & 0.078 \\
\hline AMCL & 83.955 & $0.68^{*}$ & -0.440 & 20.163 & 63.792 & 0.125 & 0.240 & 0.862 \\
\hline Eastern Bank Ltd. & 143.024 & $0.68^{*}$ & 1.023 & 20.118 & 122.906 & 0.173 & 0.141 & 2.324 \\
\hline Uttara Finance \& Invest. & 94.896 & $0.66^{*}$ & 0.333 & 19.176 & 75.720 & 0.136 & 0.202 & 1.603 \\
\hline Lexco International & 193.836 & $0.61 *$ & -1.128 & 16.305 & 177.530 & 0.208 & 0.084 & 0.043 \\
\hline Aziz Pipes & 192.128 & $0.60 * *$ & -1.962 & 15.584 & 176.544 & 0.208 & 0.081 & -0.817 \\
\hline Raspit Inc.BD. Ltd. & 67.074 & $0.59 *$ & -0.248 & 15.354 & 51.721 & 0.112 & 0.229 & 0.888 \\
\hline The IBN Sina Pharma. & 74.733 & $0.57^{*}$ & 0.462 & 14.478 & 60.255 & 0.121 & 0.194 & 1.566 \\
\hline Sinobangla Ind. Ltd. & 168.340 & $0.57^{*}$ & -1.589 & 14.278 & 154.061 & 0.194 & 0.085 & -0.494 \\
\hline $\mathrm{BOC}$ & 60.163 & $0.56^{*}$ & 0.268 & 13.930 & 46.233 & 0.106 & 0.232 & 1.350 \\
\hline GQ ball pen & 226.650 & $0.55^{* *}$ & -1.023 & 13.286 & 213.364 & 0.228 & 0.059 & 0.034 \\
\hline Rahima food corporation & 226.650 & $0.55^{* *}$ & -1.023 & 13.286 & 213.364 & 0.228 & 0.059 & 0.034 \\
\hline Federal Insurance Co. & 118.656 & $0.54 *$ & -0.649 & 12.924 & 105.732 & 0.161 & .109 & 0.393 \\
\hline H.R.Textiles ltd. & 87.100 & $0.53 *$ & -0.707 & 0.806 & 86.294 & 0.135 & 0.140 & 0.304 \\
\hline Atlas Bangladesh & 124.242 & $0.52 *$ & 0.032 & 11.890 & 112.352 & 0.166 & 0.096 & 1.032 \\
\hline Dhaka Bank Ltd. & 153.185 & $0.52 *$ & 0.633 & 11.824 & 141.361 & 0.186 & 0.077 & 1.631 \\
\hline Al Arafa Islami Bank & 85.115 & $0.51^{*}$ & 0.401 & 11.549 & 73.565 & 0.137 & 0.139 & 1.258 \\
\hline Tripti Industries Ltd. & 139.967 & $0.49 *$ & -1.260 & 10.747 & 129.221 & 0.178 & 0.077 & -0.309 \\
\hline United Insurance Co. & 48.886 & $0.49 *$ & 0.494 & 10.380 & 38.506 & 0.097 & 0.212 & 1.429 \\
\hline National polymer industries & 131.574 & $0.48^{*}$ & 0.584 & 10.145 & 121.429 & 0.172 & 0.077 & 1.508 \\
\hline
\end{tabular}


Mollik \& Khokan Bepari | Risk-Return Trade-off in Emerging Markets: Evidence from DSE

\begin{tabular}{|c|c|c|c|c|c|c|c|c|}
\hline Apex Spinning \& Knitting & 55.376 & $0.47 *$ & 0.381 & 9.838 & 45.538 & 0.105 & 0.178 & 1.291 \\
\hline Purbali General insurance & 97.858 & $0.45 *$ & -0.546 & 8.833 & 89.026 & 0.147 & 0.090 & 0.316 \\
\hline Monno Ceramic & 65.183 & $0.43 *$ & -1.216 & 8.008 & 57.176 & 0.118 & 0.123 & -0.395 \\
\hline Islami bank limited & 105.412 & $0.42 * *$ & 0.385 & 7.924 & 97.488 & 0.154 & 0.075 & 1.210 \\
\hline Bata Shoe Co. Ltd. & 28.732 & $0.42 *$ & 0.052 & 7.729 & 21.004 & 0.072 & 0.269 & 0.859 \\
\hline Standard Ceramic Ind. & 116.235 & $0.38^{* *}$ & -0.693 & 6.435 & 109.800 & 0.164 & 0.055 & 0.043 \\
\hline National tea company ltd. & 144.501 & $0.36^{* * *}$ & -0.391 & 5.694 & 138.807 & 0.184 & 0.039 & 0.301 \\
\hline Monno Fabrics & 137.578 & $0.36 * * *$ & -0.790 & 5.545 & 132.033 & 0.179 & 0.040 & -0.107 \\
\hline Wonderland Toys Ltd. & 188.085 & 0.35 & -1.563 & 5.355 & 182.730 & 0.211 & 0.028 & -0.892 \\
\hline Kay Que Bangladesh ltd & 118.889 & $0.33 * * *$ & -0.291 & 4.709 & 114.180 & 0.167 & 0.040 & 0.339 \\
\hline Reneta Ltd. & 64.381 & $0.32 *$ & 2.349 & 4.612 & 59.769 & 0.121 & 0.072 & 2.972 \\
\hline Mita Textile & 101.316 & $0.31 * *$ & -0.451 & 4.266 & 97.050 & 0.154 & 0.042 & 0.148 \\
\hline Altex industries & 302.626 & 0.31 & -0.241 & 4.183 & 298.443 & 0.270 & 0.014 & 0.353 \\
\hline IDLC & 93.704 & $0.29 * * *$ & 0.787 & 0.969 & 92.735 & 0.148 & 0.039 & 1.338 \\
\hline Immam Button & 91.170 & $0.274 * * *$ & -0.458 & 0.945 & 90.225 & 0.146 & 0.036 & 0.070 \\
\hline Sixth ICB Mutual Fund & 52.422 & $0.272^{* *}$ & & 3.263 & 49.149 & 0.110 & 0.062 & 1.331 \\
\hline BATBCL & 68.411 & $0.270^{* *}$ & -0.144 & 3.212 & 65.199 & 0.126 & 0.047 & 0.376 \\
\hline Third ICB Mutual Fund & 62.770 & $0.27 * *$ & 0.700 & 3.106 & 59.664 & 0.121 & 0.049 & 1.211 \\
\hline Ashraf Textile & 144.657 & 0.26 & -0.535 & 3.024 & 141.633 & 0.186 & 0.021 & -0.031 \\
\hline Aramit Ltd. & 43.780 & $0.26^{* *}$ & 0.244 & 3.006 & 40.775 & 0.100 & 0.069 & 0.925 \\
\hline Orion infusion ltd. & 154.323 & $0.25 * * *$ & 0.888 & 2.847 & 151.476 & 0.133 & 0.019 & 1.349 \\
\hline Wata Chemicals Ltd. & 150.34 & 0.25 & -0.757 & 2.826 & 147.514 & 0.190 & 0.019 & -0.269 \\
\hline Shaiham Textile Mills ltd. & 100.053 & 0.25 & -0.299 & 2.692 & 97.361 & 0.154 & 0.027 & 0.177 \\
\hline Modern dyeing & 75.156 & $0.25 * * *$ & -0.890 & 2.671 & 72.485 & 0.133 & 0.035 & -0.419 \\
\hline Meghna shrimp & 133.814 & $0.24 * * *$ & -1.874 & 2.600 & 131.214 & 0.134 & 0.019 & -1.406 \\
\hline Tallu Spinning Ltd. & 129.559 & $0.24 * * *$ & -0.478 & 2.455 & 127.104 & 0.126 & 0.019 & -0.023 \\
\hline Somorita Hospital & 109.507 & $0.22 * * *$ & -0.009 & 2.116 & 107.392 & 0.120 & 0.019 & 0.413 \\
\hline Apex Finishing \& Weaving & 83.589 & $0.19 * * *$ & 0.690 & 1.616 & 81.973 & 0.110 & 0.019 & 1.058 \\
\hline Pharmaco International Ltd & 241.461 & $0.18 * * *$ & -0.979 & 1.475 & 239.987 & 0.100 & 0.006 & -0.627 \\
\hline Paper processing & 185.653 & $0.18 * * *$ & -1.560 & 1.370 & 184.284 & 0.101 & 0.007 & -1.221 \\
\hline Aramit Cement & 185.489 & $0.18^{* * *}$ & -0.028 & 1.346 & 184.143 & 0.102 & 0.007 & 0.308 \\
\hline Kohinoor Chemicals ltd. & 10.422 & $0.17 * * *$ & 0.796 & 0.225 & 10.197 & 0.101 & 0.022 & 0.934 \\
\hline Gulf Foods Ltd. & 205.652 & 0.16 & -1.472 & 2.199 & 203.453 & 0.223 & 0.006 & -1.156 \\
\hline Progoti Insurance ltd. & 63.730 & 0.15 & -0.091 & 0.950 & 62.780 & 0.124 & 0.015 & 0.192 \\
\hline Mithun Knitting \& Dyeing & 90.675 & 0.14 & 0.190 & 0.839 & 89.836 & 0.148 & 0.009 & 0.455 \\
\hline Bangas Limited & 83.504 & 0.13 & 0.442 & 0.749 & 82.756 & 0.142 & 0.009 & 0.693 \\
\hline Samata Leather & 189.039 & 0.13 & -1.182 & 0.688 & 188.350 & 0.214 & 0.004 & -0.941 \\
\hline Rahman Chemicals & 181.049 & 0.12 & -0.004 & 0.614 & 180.435 & 0.210 & 0.003 & 0.223 \\
\hline Sajib Kintwear \&Garments & 198.218 & 0.10 & -1.400 & 0.473 & 197.745 & 0.220 & 0.002 & -1.200 \\
\hline Reckit Benkeiser ltd. & 460.909 & 0.09 & -2.793 & 0.322 & 460.586 & 0.335 & 0.001 & -2.628 \\
\hline Mona Food Industries & 134.858 & 0.08 & -1.889 & 0.247 & 134.612 & 0.181 & 0.002 & -1.745 \\
\hline Bangladesh Monospool & 173.749 & 0.04 & -1.638 & 0.064 & 173.685 & 0.206 & 0.000 & -1.565 \\
\hline M. Hossain Garments.. & 124.060 & 0.00 & -2.368 & 0.000 & 124.060 & 0.174 & 0.000 & -2.374 \\
\hline Renwick Jeanswear & 321.780 & -0.02 & 0.874 & 0.009 & 321.771 & 0.280 & 0.000 & 0.846 \\
\hline Rose Heaven Ball pens ltd. & 1031.050 & -0.03 & -1.339 & 0.043 & 1031.006 & 0.502 & 0.000 & -1.339 \\
\hline Tulip Dairy Product & 156.462 & -0.03 & -1.836 & 0.046 & 156.416 & 0.195 & 0.000 & -1.899 \\
\hline Padma oil co. ltd. & 85.866 & -0.03 & 2.478 & 0.047 & 85.819 & 0.145 & 0.001 & 2.415 \\
\hline MAQ Enterprises ltd & 220.355 & -0.04 & -1.164 & 0.077 & 220.278 & 0.232 & 0.000 & -1.244 \\
\hline Quasem silk mills & 237.801 & -0.07 & -1.511 & 0.194 & 237.608 & 0.241 & 0.001 & -1.638 \\
\hline Perfume chemical ind. & 190.952 & -0.19 & -0.266 & 1.628 & 189.324 & 0.215 & 0.009 & -0.636 \\
\hline Shyam Sugar Mills Ltd. & 443.619 & -0.30 & 0.875 & 0.614 & 20.448 & 0.327 & 0.009 & 0.289 \\
\hline
\end{tabular}

*Significant at $1 \%$ level; **Significant at $5 \%$ level; *** Significant at $10 \%$ level. 